\title{
THE EFFECT OF VARIOUS TREATMENTS OF CULTURE MEDIUM UPON THE GROWTH OF CERTAIN FUNGAL ANTAGONISTS
}

\author{
LEILA-RiItTA ERViö \\ Department of Plant Pathology, University of Helsinki
}

Received December 18, 1964

Many soil fungi have been found to be antagonists of Sclerotinia trifoliorum Erikss., S. sclerotiorum (LiB.) Bref. and Botrytis cinerea Pers. (1, 2, 9, 10). Since external conditions have an influence on these antagonists $(3,4,5)$ and thus indirectly affect their ability to suppress the occurrence of harmful parasitic fungi of cultivated plants, this study dealt with the effect of various treatments of culture medium upon the growth of such soil fungi, whose antagonism is based on their capacity to destroy the sclerotia of their hosts.

\section{Materials and methods}

The following fungal antagonists, which have been found to be antagonists of $S$. trifoliorum, S. sclerotiorum and B. cinerea, were used in these studies:

Acrostalagmus roseus BANIER, isolate I (cf. 10). Isolated from a sclerotium of S. trifoliorum in 1954 .

A. roseus, isolate II. Isolated from a sclerotium of S. trifoliorum in 1963.

Coniothyrium minitans, САмРB., isolate I. Isolated from foreign red clover seed in 1962 .

C. minitans, isolate II. Isolated from a sclerotium of S. trifoliorum in 1962.

Fusarium avenaceum (FrIES) SACC. Isolated from carnation at the Department of Plant Pathology, Tikkurila, in 1955.

Gliocladium roseum (Link) THом. (cf. 7). Isolated from a sclerotium of $S$. trifoliorum in 1955.

Gliocladium sp. Isolated from a sclerotium of S. trifoliorum in 1955.

Mucor hiemalis WEнM. (cf. 7). Isolated from a sclerotium of Claviceps purpurea in 1959 . 
M. spinosus TiEgh. Isolated from Henneberg agar medium treated with pentachloronitrobenzene in 1962.

Rhizopus nigricans EHRENB. Isolated from dead clover in 1962.

Sporotrichum carnis BROOKS \& HANSF. Isolated from a sclerotium of S. trifoliorum in 1962.

Trichoderma viride (TODE) HARTz (cf. 7). Isolated from a sclerotium of $S$. trifoliorum in 1955.

Trichothecium roseum LiNk. Isolated from mycelia of $S$. trifoliorum in potato stem in 1963.

The fungi were cultured on a basic medium consisting of Henneberg agar (10 g peptone, $2 \mathrm{~g} \mathrm{NH}_{4} \mathrm{H}_{2} \mathrm{PO}_{4}, 2 \mathrm{~g} \mathrm{KNO}_{3}, 0.5 \mathrm{~g} \mathrm{MgSO}_{4}, 0.1 \mathrm{~g} \mathrm{CaCl}_{2}, 100 \mathrm{~g}$ glucose, $20 \mathrm{~g}$ agar and $1000 \mathrm{ml}$ distilled water). In the different trials the following additions were made to the basic medium:

Potassium was added at a rate of $200 \mathrm{~g} / \mathrm{m}^{2}$ in the form of $50 \%$ potassium chloride $(\mathrm{KCl})$ or as potassium sulphate $\left(\mathrm{K}_{4} \mathrm{SO}_{4}\right)$.

In the tests with pentachloronitrobenzene (PCNB), Brassicol dust at rates of 50 and $100 \mathrm{~g} / \mathrm{m}^{2}$ was applied to the solidified surface of the agar in the Petri dishes.

The $\mathrm{pH}$ of the Henneberg agar — normally 6.7 - was made more acidic by adding $10 \%$ hydrogen chloride $(\mathrm{HCl})$ or more basic by adding $10 \%$ potassium hydroxide $(\mathrm{KOH})$.

In addition to the above treatments, the effect of oxygen deficiency on the growth of the fungi was studied by sealing the Petri dishes with modelling clay after inoculation of the fungi. The control dishes were left unsealed.

The fungi were transferred with an inoculating needle to the centre of the agar medium in the Petri dish, and the size of the colony was measured from time to time. In determining the effect of PCNB, the vigour of the fungal growth was estimated visually on a scale of $0-3$. All the trials were carried out at room temperature in the laboratory. The control organism used was $S$. trifoliorum which had been isolated in the autumn of 1960 from a first-year clover ley at Viik.

\section{Results}

Effect of potassium. The addition of potassium - either as chloride or as sulphate - had no appreciable effect on the growth of the fungi (Fig. 1). The differences in colony size of the same isolate on the differently treated plates were either very small or completely lacking.

Effect of pentachloronitrobenzene (PCNB). The fungi in these tests were cultivated on Henneberg agar which had been treated with Brassicol dust, and their growth was compared with that of fungi on untreated plates. It was found that the different isolates responded differently to PCNB. All of them grew more poorly on the treated than on the control medium on which their growth 


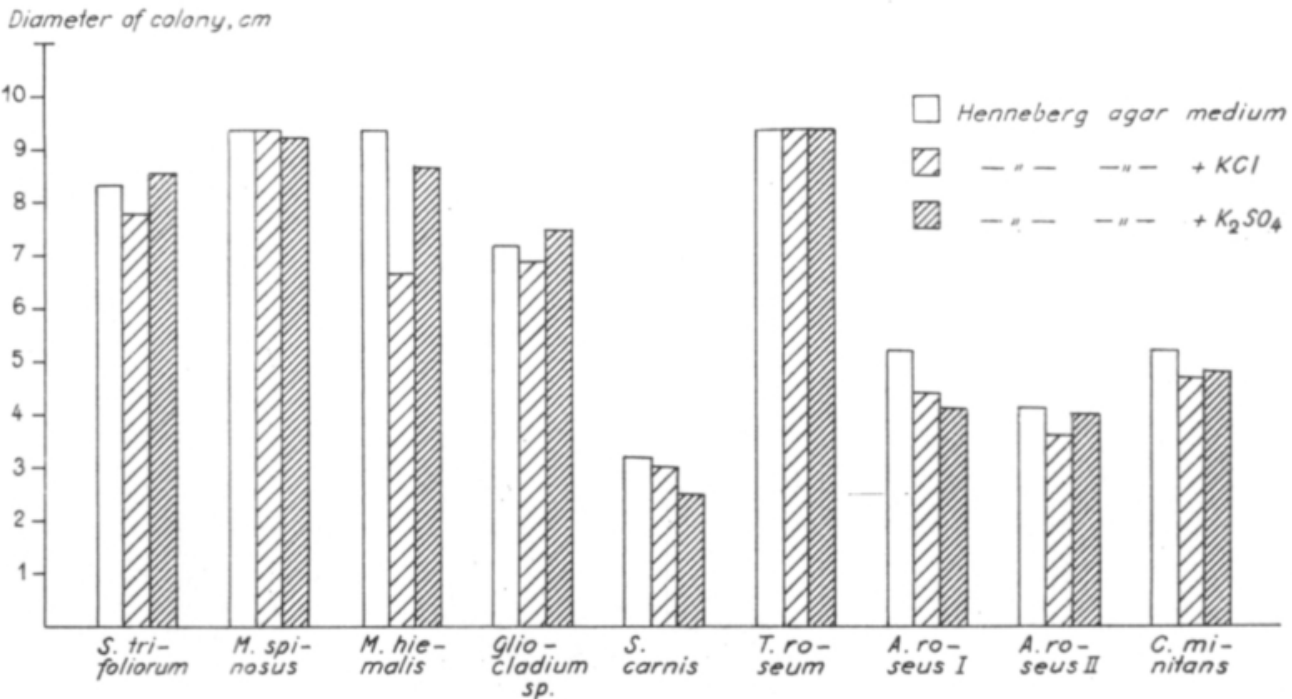

Fig. 1. The effect of potassium on the growth of some fungi. The trial period was 14 days.

was rated as $n 3 n$ on the scale. In comparison with that the fungi grew on the PCNBtreated medium as seen below:
S. trifolionum
A. roseus I
A. roseus II
C. minitans I
C. minitans II
0

Gliocladium sp.

$M$, hiemalis

M. spinosus

$R$. nigricans

S. carnis

The species S. trifoliorum, $R$. nigricans and S. carnis were most sensitive to PCNB since their development ceased completely. In contrast, such parasites of $S$. trifoliorum as A. roseus, Gliocladium sp. and $M$. spinosus were considerably more resistant to the chemical.

The tolerance of $A$. roseus isolate II to PCNB was further studied by culturing it for 4 weeks on Henneberg agar to which Brassicol dust had been added at rates of 50 and $100 \mathrm{~g} / \mathrm{m}^{2}$. According to the results shown below, the fungus grew relatively well at both consentrations.

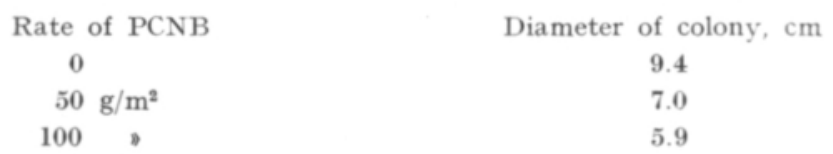

$\mathrm{E} f \mathrm{fect}$ of $\mathrm{pH}$. It is generally known that fungi can exist over a wide range of $\mathrm{pH}$ values $(6,8)$. In the present tests, S. trifoliorum, A. roseus I, Gliocladium sp., $T$. roseum and $T$. viride were cultivated on Henneberg agar whose $\mathrm{pH}$ varied by 1-unit intervals from 2 to 9 . It was found that all the fungi grew when the $\mathrm{pH}$ was between 4 and 9 . The $\mathrm{pH}$ optimum of $S$. trifoliorum was $4-6$ while Gliocladium $\mathrm{sp}$. and $A$. roseus favoured a more alkaline substrate. $T$. viride was the only fungus which grew at $\mathrm{pH} 2$. In this highly acidic medium, however, the appearance of the colony 
differed from normal: it was slimy and pale-coloured, and no conidia were formed. At $\mathrm{pH} 8-9$ the normal green colour of this fungus changed to yellow; abundant formation of conidia was not inhibited.

Effect of oxygen deficiency. A deficiency in the oxygen supply slowed the development of S. trifoliorum, A. roseus I and II, M. hiemalis and $T$. viride. Toward the end of the 4-week trial period their growth stopped completely. In such dishes no conidia were formed, nor did $S$. trifoliorum produce sclerotia. However, even four months after the end of the trial, all the fungi in the sealed dishes were still viable.

$$
\text { Conclusions }
$$

The addition of potassium chloride and potassium sulphate at a rate of 200 $\mathrm{g} / \mathrm{m}^{2}$ to the culture medium had no effect on the growth of Sclerotinia trifoliorum, Acrostalagmus roseus I and II, Coniothyrium minitans, Gliocladium sp., Mucor hiemalis, M. spinosus, Sporotrichum carnis and Trichothecium roseum.

Treatment of the culture medium with PCNB suppressed to some extent the development of A. roseus I and II, Gliocladium sp., C. minitans I and II, Mucor hiemalis and M. spinosus. The fungal species S. trifoliorum, Rhizopus nigricans and Sporotrichum carnis did not grow at all on PCNB-treated medium.

$S$. trifoliorum, A. roseus I, Gliocladium sp., T. viride and $T$. roseum were able to grow in the $\mathrm{pH}$ range of $4-9$. When the $\mathrm{pH}$ of the medium was 2 , only $T$. viride grew,

Oxygen deficiency suppressed the growth of $S$. trifoliorum, and the growth and the conidia formation of $A$. roseus I and II, $M$. hiemalis and $T$. viride.

\section{RE F E R E N C E S}

(1) ERvıö, L-R. Certain parasites of fungal sclerotia. Maatal.tiet. aikak. 1965, painossa.

(2) - - Halkilahti, A-M. \& Ронјакаllio, O. 1964. The survival in the soil of sclerotia of two Sclerotinia species and their ability to form mycelia. Repr. from Advancing Frontiers of Plant Sci. 8: $121-134$.

(3) Garket, S. D. 1956. Biology of root infecting fungi. 292 p. Cambridge.

(4) Halkilahti, A-M 1962. The survival of sclerotia of Sclerotinia trifoliorum ERIKss. on the soil and the occurence of clover rot in various years. Maatal.tiet. aikak. 34: 154-161.

(5) - 1964. The significance of soil microorganisms as a limiting factor in infection of clover by Sclerotinia trifolionum ERIKSS. at different times of the year. Ibid. 36: 120-134.

(6) Jensen, H. L. 1931. The fungus flora of the soil. Soil Sci. 31: 123-158.

(7) Karhuvana, L. 1960. On the parasites of the sclerotia of some fungi. Acta Agr. Scand. 10: 127 -134 .

(8) Kaufman, D. D. \& Williams, L. E. 1964. Effect of mineral fertilization and soil reaction on soil fungi. Phytopath. 54: 134-139.

(9) Makkonen R. \& Pohjakallio, O. 1960. On the parasites attacking the sclerotia of some fungi pathogenic to higher plants and on the resistance of these sclerotia to their parasites. Acta Agr. Scand. 10: 105-126.

(9) Ронјакаllio, O. 1960. Untersuchungen über Antagonisten der Erreger von Pflanzenkrankheiten. Verhandl. IV Intern. Pflanzenschutz. Kongresses Hamburg 1957 Bd. 2: 1541-1543.

(10) - - SAlonen, A., Ruokola, A-L. \& Ікйнеimo, K. 1956. On a mucous mold fungus $\mathrm{Acrosta-}$ lagmus roseus BAINIER, as antagonist to some plant pathogens. Acta Agr. Scand. 3: 53-60. 


\title{
KASVUALUSTAN ERILAISTEN KÄSITTELYJEN VAIKUTUKSESTA ERÄIDEN TUHOSIE- NIEN ANTAGONISTIEN KASVUUN
}

\author{
LEILA-RIITTA ERVIÖ
}

Yliopiston kasvipatologian laitos, Helsinki

Tutkittaessa kasvualustan erilaisten käsittelyjen vaikutusta eräiden maasienien kasvuun, todettiin, että kaliumkloridin $(\mathrm{KCl})$ ja kaliumsulfaatin $\left(\mathrm{K}_{2} \mathrm{SO}_{4}\right) 200 \mathrm{~g} / \mathrm{m}^{2}$ vastaava lisäys ravintoalustaan ei vaikuttanut Sclerotinia trifoliorumin, Acrostalagmus roseus $\mathrm{I}: \mathrm{n}$ ja II:n, Coniothyrium minitansin, Gliocladium sp:n, Mucor hiemalisen, M. spinosusen, Sporotrichum carnisen ja Trichothecium roseumin kasvuun.

Ravintoalustan käsittely PCNB:llä heikensi jonkin verran $A$, roseus I:n ja II:n, Gliocladium sp:n, C. minitans I:n ja II:n, Mucor hiemalisen sekä $M$. spinosusen kasvua. Sensijaan $S$. trifoliorum, Rhizopus nigricans ja Sporotrichum carnis eivät kasvaneet olleenkaan PCNB:llä käsitellyllä ravintoalustalla.

Sienien S.trifoliorum, A. roseus I, Gliocladium sp., $T$. viride ja $T$. roseum todettiin menestyvän $\mathrm{pH}$ rajoissa 4-9. Ravintoalustan $\mathrm{pH}$-arvon ollessa 2 kasvoi vain $T$. viride.

Hapenpuute hidasti sienien $S$. trifoliorum, A. roseus I ja II, $M$. hiemalis ja $T$, viride kasvua ja kuromanmuodostusta. 